\title{
Design and Performance Analysis of a Clean Energy Installation for Residential Use
}

\author{
I. Zamora*, J.I. San Martin, P. Eguía, V. Aperribay, J.J. San Martin, O. Oñederra, F.J. Asensio, \\ J. García-Villalobos
}

Department of Electrical Engineering - University of the Basque Country, 48013 Bilbao, Spain

*Corresponding Author: inmaculada.zamora@ehu.es

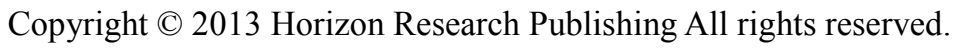

\begin{abstract}
Two of the primary energy demands of residential customers are electricity and fuel for road transport. The ideal solution would be to address those necessities using renewable resources. To accomplish this goal, various green technologies have already been developed to supply electricity. From the point of view of road transport, hydrogen is a clean energy source that is more efficient than other fossil fuels used to date. However, its use in this field is still limited, not only because of technical and economic limitations of the vehicle itself but also due to the need for large hydrogen refuelling stations. For that reason, the primary objective of this paper is to present the design and performance of a residential hydrogen fuelling station based on water electrolysis. To obtain more complete and efficient performance, the design has been developed to take into consideration the power consumption of the residence itself. In addition, also the power surplus will be sold to the electrical grid to help recover the investment.The option selected for producing the required power and hydrogen is wind energy, due to the favourable characteristics of efficiency, reliability, cost and safety of this resource. Moreover, an analysis of the performance of the designed installation has been evaluated through a simulation with Matlab/SimPowerSystem. An estimation of the costs has also been developed.
\end{abstract}

Keywords Wind energy, Hydrogen, Electricity, Fuel Cell Vehicle, Residential Installation, Simulation

\section{Introduction}

Concern about limited fossil resources and global climate change is leading to the pursuit of clean energy sources to meet the growing energy demand [1-2]. In this context, renewable energies appear to be an increasingly important primary fuel source. Hydrogen can optimally replace fossil fuels, particularly in the transportation sector, which represents the greatest consumer of oil worldwide [3].
Hydrogen can be used for automotive applications, either in a combustion engine that uses hydrogen as a fuel or in a fuel cell installed on the vehicle. The United States Department of Energy has specified long-term objectives for the development of fuel cell vehicles. In 2015, it is expected that fuel cells will achieve an efficiency of $60 \%$, a cost of $\$ 30 / \mathrm{kW}$ and a rated life of at least 5,000 hours, which is equivalent to

a distance of $240,000 \mathrm{~km}$, travelling at $48 \mathrm{~km} / \mathrm{h}$ [4-6]. However, one of the primary obstacles for the implementation of fuel cell vehicles is the lack of a hydrogen distribution infrastructure [7].

One possibility currently addressed is the residential production of hydrogen, which can be obtained from the catalytic cracking of natural gas, the catalytic cracking of biogas residentially generated, the electrolysis of water using power from the electrical grid or the use of electricity generated by renewable energy sources [8-9]. From an environmental perspective, the production of hydrogen for use as fuel makes sense if it is obtained using renewable energy sources or if the method used to recover the energy content is efficient enough to compensate for the energy used in its production. Thus, the latter method, using wind power or solar radiation, combines the two requirements for a residential application: (a) the power source is usually available where it is needed, and (b) they are sufficiently developed technologies. The hydrogen generation option for this design has therefore focused on water electrolysis using power from wind energy. To make better use of local renewable resources, the rainwater that falls on the roof of the residential garage is used as the primary water source.

In this context, this paper focuses on the design and performance analysis of an installation that can provide:

- A residential hydrogen fuelling station to feed fuel cell-based private vehicles

- A power supply for the consumption of the residence

- The possibility of selling power to the electrical grid when surplus exists

This installation will run on electricity obtained from four vertical axis wind turbines of $4 \mathrm{~kW}$ each. The choice of wind turbines instead of photovoltaic modules is based on aspects 
related to the efficiency of both technologies [10]. For the implementation of the wind turbine-based system, a map of wind speed distribution has been analysed [11]. The electricity obtained is used to feed the electrical loads of the residence and an electrolyser to split water into hydrogen and oxygen [12-13]. If necessary, electricity supplied from the grid could be taken during periods of low wind activity. This combination of resources ensures the supply of electricity and hydrogen.

Once it has been designed, the correct performance of the installation has been validated through dynamic simulations using the software Matlab. Finally, an economic analysis has also been included.

\section{Installation Technical Design}

The installation design strategy, which includes the power supply to the residential loads and the power required to feed the residential fuelling station with hydrogen, is based on three operation modes:

- Four wind turbines provide the electricity required during normal operation. In subsection 2.9, the number of wind turbines is justified.

- In a prolonged absence of wind, the electricity required is obtained from the electrical grid.

- If the hydrogen storage tank is full and the electricity consumption of the residence is covered, the power surplus from the wind turbines is sold to the electrical grid.

Figures 1 and 2 illustrate the block diagram of the proposed installation, with a special emphasis on the devices required for the hydrogen residential fuelling station and the distribution of the hydrogen station devices inside the garage. The modus operandi of this installation is the following:

- Electricity is provided from the vertical axis wind turbines and, if necessary, from the grid.

- To optimise the system, most of the water for the electrolysis process is expected to come from the rain. This process will not be interrupted due to a lack of water. Additionally, the water used for electrolysis will be subjected to a process of deionisation. Wind and rainwater are therefore the primary energy sources used to obtain the hydrogen, which can reduce the traditional fuels used in road transportation.

- A compressor operating at 42 megapascals (MPa) compresses the hydrogen produced in the electrolyser. The oxygen obtained from this process can be used as a by-product for other purposes.

- The hydrogen generated is stored in a tank at $42 \mathrm{MPa}$.

- The hydrogen from the storage tank is conducted to the hydrogen dispenser to refuel the vehicle.

In this section, issues related to power consumption/production and the components comprising the installation are described. The following requirements have been considered for the design and performance analysis presented in this paper:

- The consumption of the residential load for a typical house has been estimated at $13.14 \mathrm{kWh} /$ day; the total consumption during a year is $4,794 \mathrm{kWh}$.

- For the design of the refuelling station for the personal vehicle, typical values of $56.3 \mathrm{~km} /$ day or $20,550 \mathrm{~km} /$ year and $70.8 \mathrm{~km} / \mathrm{kg}$ of hydrogen consumption have been assumed.

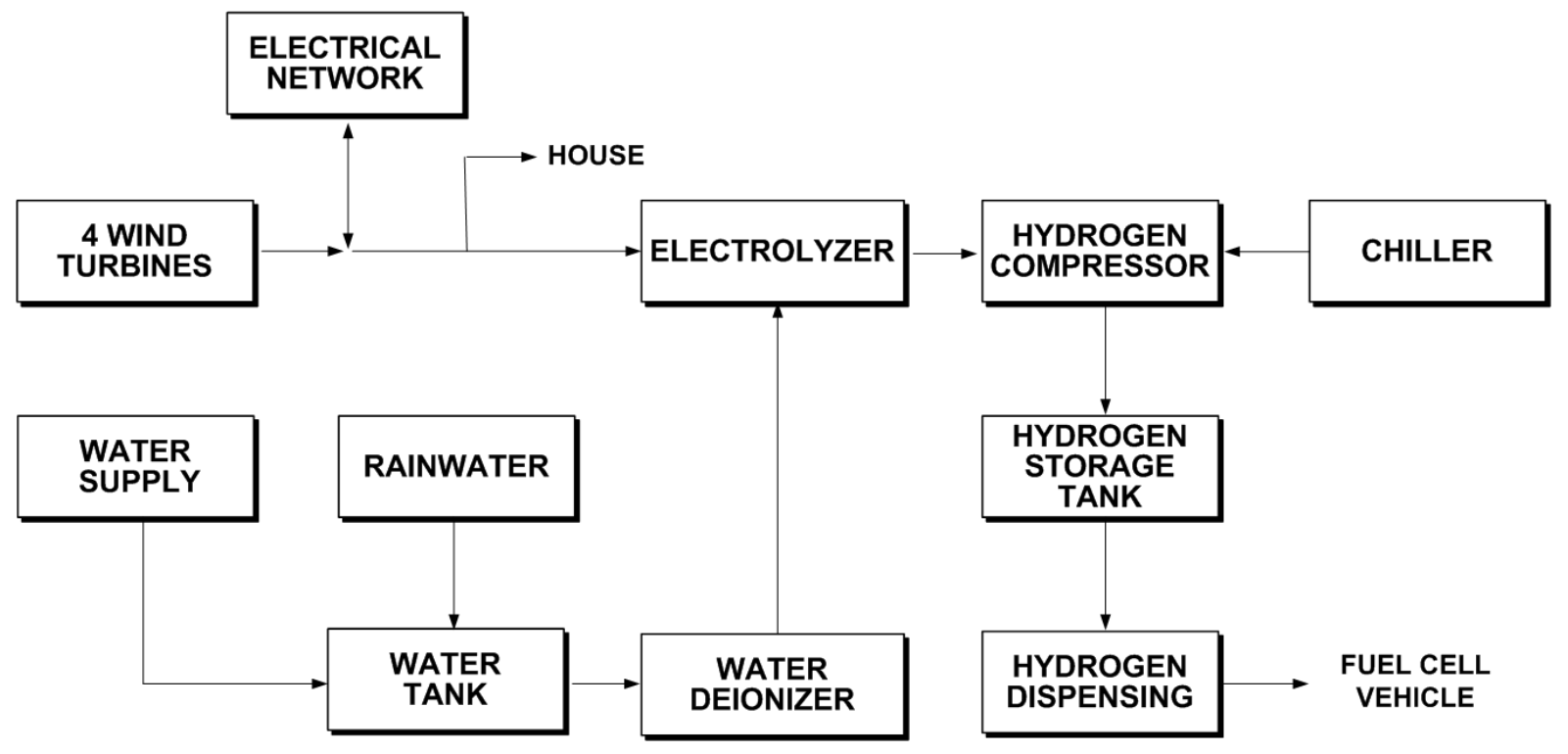

Figure 1. Diagram of the designed installation 


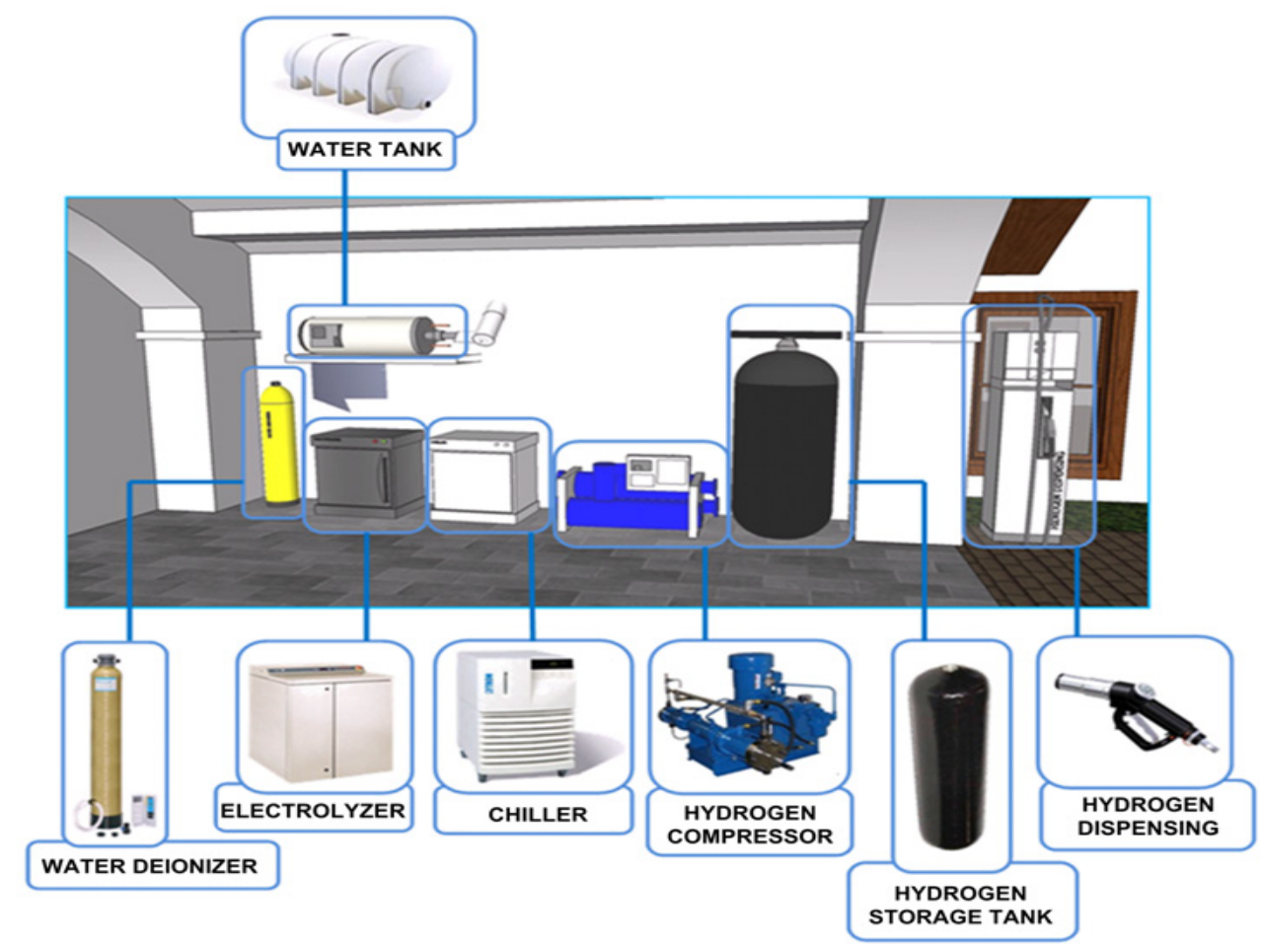

Figure 2. Distribution of devices, inside the garage

\subsection{Electrolyzer}

There are two main types of electrolysers: those built with an alkaline electrolyte membrane and those built with a proton exchange membrane (PEM). For the latter, the cost is greater due to the use of fluorinated membranes and noble metal electrodes. However, they are more versatile and have greater efficiency. The PEM electrolyser has the reverse operation process of a PEM fuel cell. The amount of hydrogen required is calculated using the vehicle requirements, as demonstrated in equation (1).

$$
\frac{56.3 \mathrm{~km}}{70.8 \mathrm{~km} / \mathrm{kg}}=0.8 \mathrm{~kg}
$$

Thus, $0.8 \mathrm{~kg}$ of hydrogen per day is necessary. Knowing that $1 \mathrm{~kg}$ of hydrogen is equivalent to $33.33 \mathrm{kWh}$ at Low Heating Value (LHV) [14], the energy consumed by the car in one day is displayed in equation (2)

$$
0.8 \mathrm{~kg} \cdot 33.33 \mathrm{kWh} / \mathrm{kg}=26.5 \mathrm{kWh}
$$

According to the manufacturer, the chosen electrolyser consumes $6.7 \mathrm{kWh}$ per $\mathrm{Nm}^{3}$ of hydrogen (Normal cubic meter, at 1 atmosphere and $0^{\circ} \mathrm{C}$ ). Moreover, one $\mathrm{Nm}^{3}$ of hydrogen is equivalent to $3 \mathrm{kWh}$ (LHV) [14-15]. From these data, the efficiency of the electrolyser can be calculated, as displayed in equation (3).

$$
\eta_{\text {electroliser }}=\frac{3 \mathrm{kWh} / \mathrm{Nm}^{3}}{6.7 \mathrm{kWh} / \mathrm{Nm}^{3}} \cdot 100=44.77 \%
$$

Once the efficiency of the electrolyser is known, the daily amount of electricity to be supplied to the electrolyser can be determined, as demonstrated in equation (4).

$$
\frac{26.5 \mathrm{kWh}}{0.4477}=59.2 \mathrm{kWh}
$$

According to the specifications of the electrolyser [15], the maximum production of hydrogen per day is $1.14 \mathrm{~kg}$. Thus, the electrolyser must be running for 16 hours and 45 minutes, at rated power, to be able to produce $0.8 \mathrm{~kg}$. Therefore, the annual energy required to supply the vehicle with hydrogen is $9,677 \mathrm{kWh}$, plus $21,615 \mathrm{kWh}$ for the electrolyser. The oxygen produced could be stored and sold as a by-product to improve the economical efficiency of the system.

\subsection{Deionizer}

The electrolyser requires deionised water for operation. Deionisation reduces the amount of dissolved minerals in water. The efficiency of deionisation equipment is determined by measuring the conductivity, resistivity or concentration of the dissolved minerals. The removal of ions produces an increase in the water resistivity, providing an accurate method for determining the degree of deionisation. As already indicated in the electrolyser data [15], the water consumption rate is $0.47 \mathrm{l} / \mathrm{hr}$, and 16 hours and 45 minutes of work are required. Therefore, for daily production, 7.87 litres of deionised water, with conductivity less than $1 \mu \mathrm{S} / \mathrm{cm}$, is required. With this water flow, the demand of $0.8 \mathrm{~kg}$ of hydrogen can be met [16]. The deioniser selected does not consume energy, thereby improving the overall efficiency of the system. 


\subsection{Water Supply}

The electrolyser receives water through the deioniser from a water storage tank. The tank is filled in two ways: rainwater and/or domestic pipe water. The tank supplies the water by gravity to operate the deioniser and the electrolyser. The tank has detectors of minimum and maximum levels to ensure adequate water flow to the electrolyser and to cut the water supply to the tank, respectively.

To choose the water tank dimensions, rainfall data in the selected area have been previously collected. The average annual precipitation is estimated to be $505 \mathrm{~mm}$. The floor space occupied by the garage roof, where the hydrogen generation system is located, is $30 \mathrm{~m}^{2}$. Thus, $30 \mathrm{~m}^{2} \cdot 0.505$ $=15.15 \mathrm{~m}^{3}=15,150$ litres, is available per year, which is an average value of $41.52 \mathrm{l} /$ day. Because the daily amount of water required for hydrogen generation is 7.87 litres, the water supply can be adequately ensured with rainwater.

Considering the previously reported numerical values, a water tank of 300 litres has been selected [17]. This tank is oversized so that it can be filled in a single day that precipitates $10 \mathrm{~mm}$. When the water tank is full, it is possible to produce hydrogen for 40 days without rain. However, if there is not enough rainwater, water from the domestic pipe can be used.

\subsection{Compressor}

To supply hydrogen to the vehicle, there must be a pressure difference between the electrolyser and the dispenser. The electrolyser supplies hydrogen at $1.38 \mathrm{MPa}$, and the vehicle requires hydrogen at approximately $35 \mathrm{MPa}$ to fill the vehicle tank. Therefore, a compressor is needed to raise the pressure of the hydrogen from the electrolyser output to store it in a tank [18]. The average consumption to compress $1 \mathrm{~kg}$ of hydrogen from $1.38 \mathrm{MPa}$ to $35 \mathrm{MPa}$ is estimated as $3.1 \mathrm{kWh}[19]$. The energy required per year is displayed in equation (5).

$$
0.8 \frac{\mathrm{kg}}{\text { day }} \cdot \frac{3.1 \mathrm{kWh}}{1 \mathrm{~kg}} \cdot \frac{365 \text { days }}{1 \text { year }}=900 \mathrm{kWh} / \text { year }
$$

\subsection{Chiller}

The heat generated during hydrogen compression must be released for proper operation of the compressor. It has been estimated that the cooling rate can be less than 0.2 $\mathrm{kWh}$ because the compressor selected is oversized and will idle most of the time. To achieve a faster cooling rate, a refrigerator unit comprising a cooling system, a cooling circuit and electronic control devices will be used [20]. The energy required per year has been estimated to be $338 \mathrm{kWh}$, considering that the compressor does not have to work continuously.

\subsection{Hydrogen Storage Tank}

One of the primary problems for the development of hydrogen technology is the need for safe and cost-effective ways of storing it. There are various possibilities for hydrogen storage, among which the following are especially promising [21-23]: compressed hydrogen, liquid hydrogen, metal hydrides and carbon-based material (e.g., fullerenes, carbon, nanotubes and activated carbons). The option chosen for this design is compressed hydrogen [24].

\subsection{Hydrogen Dispensing}

The fuel gas dispenser is a "stand-alone" unit, which provides the mechanical interface between the hydrogen fuel station storage tank and the vehicle, along with safety features and metering equipment. The dispenser consists of a small enclosure where the regulation and control valves are located [25].

\subsection{Wind Turbine}

The wind turbine must at least supply the energy consumed by the loads of the residence, the electrolyser, the compressor and the chiller. The criteria for selecting the most suitable wind turbine for the chosen site is presented. The average direction of winds in the selected area have been measured at a height of $50 \mathrm{~m}$ above the $1,074 \mathrm{~m}$ of altitude of the site. The wind speed data have been translated to a height of $10 \mathrm{~m}$, which is the height of the wind turbines to be installed [26], as presented in (6).

In this equation, $\mathrm{v}$ is the wind speed, $\mathrm{h}$ is the height at which the wind speed is measured, and $\alpha$ is a parameter called the 'roughness coefficient', which is dependent on the topography and weather conditions. For the design presented in this paper, a value of $\alpha=0.14$ has been chosen [26].

$$
\frac{\mathrm{v}_{1}}{\mathrm{v}_{2}}=\left(\frac{\mathrm{h}_{1}}{\mathrm{~h}_{2}}\right)^{\alpha}
$$

Next, the annual wind speed data histogram has been approximated by a continuous curve using a two-parameter Weibull probability density function. The Weibull function is defined in equation (7) [26].

$$
f(v)=\frac{\beta}{\alpha}\left(\frac{v}{\alpha}\right)^{\beta-1} e^{\left[-\left(\frac{v}{\alpha}\right)^{\beta}\right]}
$$

Where $\mathrm{v}$ is the wind speed, $\alpha$ is the roughness coefficient and $\beta$ is the shape parameter. The optimal values of $\alpha$ and $\beta$ that adjust the Weibull function to the wind speed data histogram have been obtained as: $\alpha=2.625$ and $\beta=7.076$.

Taking into account the energy requirement and the wind distribution in the site area, the vertical axis UGE-4K wind turbine has been chosen [27]. Multiplying the power curve of this wind turbine by the wind speed distribution, it yields the energy curve illustrated in Figure 3. This curve indicates the energy produced by the wind turbine for every wind 
speed value. The area below the curve indicates the energy produced by the wind turbine in one year, which corresponds to a value of approximately 7,755.42 $\mathrm{kWh} /$ year.

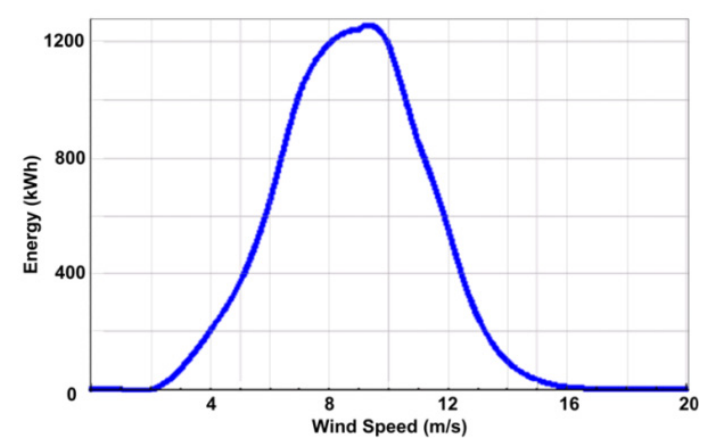

Figure 3. Electricity produced as a function of wind speed

\subsection{Electricity Supply}

The electricity required for the operation of the electrical loads and the residential fuelling station is primarily supplied by vertical axis wind turbine generators located in the residence, close to the main building. Considering visual aspects, each wind turbine tower also contains one streetlight. For this design, the expected consumption of energy, justified in previous subsections, is calculated using equation (8).

$$
4,794+21,615+900+338=27,647 \mathrm{kWh} / \text { year }
$$

Thus, with four wind turbines, the energy produced per year equals $31,021 \mathrm{kWh}(4 \times 7,755.42 \mathrm{kWh} /$ year $)$, enough to supply the entire energy needs. If the generation needs are covered by the wind turbines, the energy surplus can be sold to the utility company, as revealed in equation (9). Conversely, in times of low or no wind, the energy required can be purchased from the electrical grid.

$$
31,021-27,647=3,374 \mathrm{kWh} / \text { year }
$$

Additionally, considering the electricity needs and the variability of the wind production, three representative days have been selected to cover the different scenarios of generation to verify the energy that could be produced with the system designed: a day of high wind, a day of typical wind and a day of low wind have been selected.

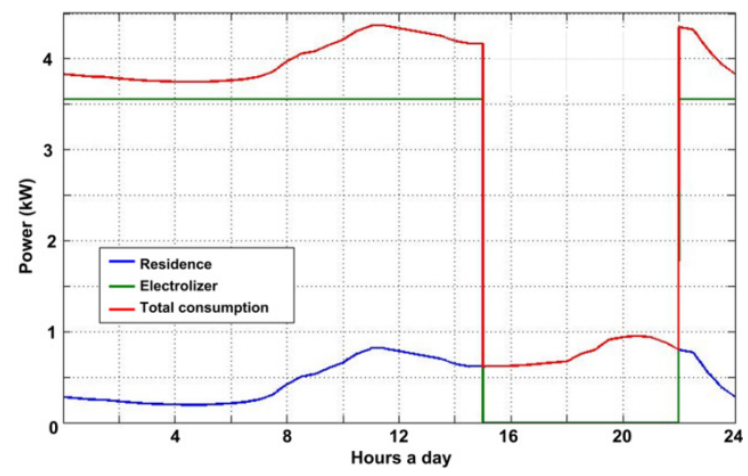

Figure 4. Residence and electrolyzer power consumption and total consumption
Figure 4 displays the load profile for the hydrogen generation system, the load of the house and the total consumption of both. Additionally, Figures 5, 6 and 7 illustrate the different profiles of generation and consumption for high-, typical- and low-wind scenarios, respectively. Negative power values indicate the consumption of electricity from the grid.

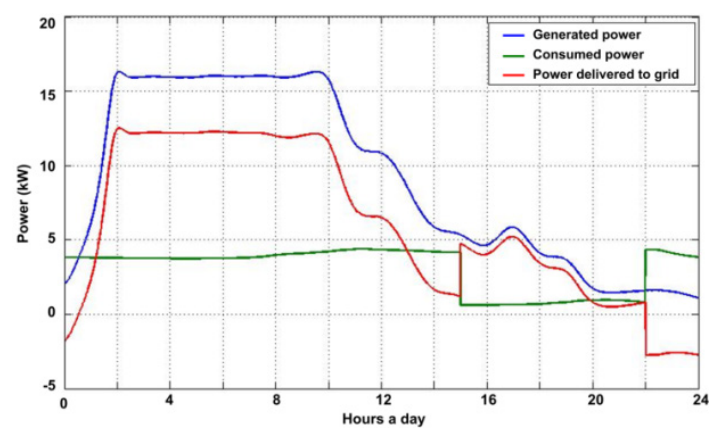

Figure 5. Generation, self consumption and grid energy exchange profiles for a high wind scenario

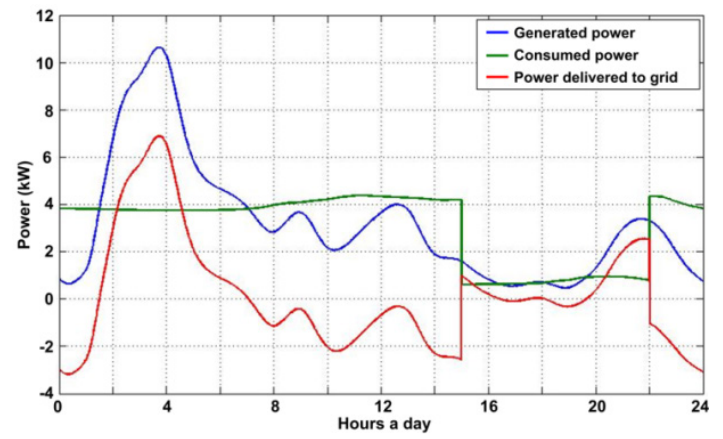

Figure 6. Generation, self consumption and grid energy exchange profiles for a typical wind scenario

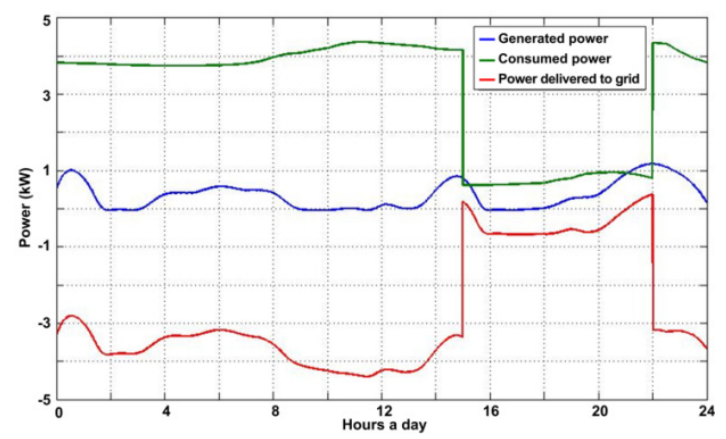

Figure 7. Generation, self consumption and grid energy exchange profiles for a low wind scenario

Given the difference between off-peak and peak hours, the ideal operation is that the hydrogen production system works the maximum time possible during off-peak hours to make the hydrogen production cheaper. Additionally, the surplus energy could be sold to the grid during peak hours, resulting in a greater benefit and improving the cost efficiency. Taking into consideration this aspect, the electrolyser is connected at 22:00 and disconnected at 14:45, obtaining the maximum number of operating hours with the most favourable rate (off-peak hours) [28]. 
Table 1. Generation and power consumption of energy, in $\mathrm{kWh}$, for the three scenarios

\begin{tabular}{lccccc}
\hline & $\begin{array}{c}\text { Generated } \\
\text { energy }\end{array}$ & $\begin{array}{c}\text { Consumed } \\
\text { energy }\end{array}$ & $\begin{array}{c}\text { Delivered at } \\
\text { off-peak hours }\end{array}$ & $\begin{array}{c}\text { Delivered at } \\
\text { peak hours }\end{array}$ & $\begin{array}{c}\text { Delivered } \\
\text { to grid }\end{array}$ \\
\hline High wind day & 218 & & 124.7 & 19.5 & 144.2 \\
Medium wind day & 77.2 & 73.5 & -0.2 & 3.9 & 3.7 \\
Low wind day & 8.4 & & -62.1 & -2.9 & -65.1 \\
\hline
\end{tabular}

Finally, Table 1 displays the energy produced by the wind turbines, the power consumed by the electrolyser and the house and the total energy exchange with the grid for the three scenarios reported.

\subsection{Connection between Devices and Safety Equipment}

For the interconnection of the system components, it is necessary to use various valves, piping, pressure relief valves, gauges and adapters. To connect the devices, pipes and adapters reported elsewhere [29] are used.

After defining the connections for fluids, the electrical connections of the system must be considered. The output voltage and frequency that provide the four wind turbines are variable, according to the specifications required by the residential customer, to meet the needs of the local electrical network where the wind turbines are connected. For this study, a generation voltage of $380 \mathrm{~V}$ between phases and a frequency of $50 \mathrm{~Hz}$ have been selected. These voltage and frequency levels correspond to the values of the domestic electrical network for which the design has been developed; thus, the system does not require any additional conditioning device for connecting components.

In addition, a safety system must be installed with the objective of reducing the risks associated with the use of hydrogen in the residential fuelling station. The safety system comprises the following elements: hydrogen leakage and flame detection systems, a venting system, a pressure relief system, an emergency stop switch and other safety systems (fire extinguisher, fire hose, safety signalling, lock, etc.).

\section{Performance Analysis through Simulation}

Once the installation has been designed, it is important to verify the correct performance of the installation in different operating conditions. The chosen option has been developed in a dynamic model of the most relevant devices comprised in the installation. For the simulation process, the Matlab/Simulink/SimPowerSystems software has been considered. Figure 8 presents the complete model, which considers the following components and processes:

- Components: permanent magnet generator for the wind turbine model, uncontrolled three-phase rectifier, IGBT three-phase inverter, an $\mathrm{L}$ filter to introduce impedance between the grid and the inverter (to be able to control the injected current to the grid), a storage tank, an electric grid and loads (electrolyser and residence).

- Processes: normal operation, reactive power injection, wind speed variation and power factor correction.

\subsection{Components Modelling}

Following, the most relevant features of the developed models are presented. Initially, the performance of each model is checked separately and then, once validated, models of all components are connected to develop different tests presented in section 3.2.

\subsubsection{Permanent Magnet Generator}

The four wind turbines have been modelled using only one permanent magnet generator with the total rated power of the four wind turbines. This model is included in the Matlab/Simulink software in the SimPowerSystems Toolbox. The parameters of the default model have been changed, as indicated in Table 2, to satisfy the real behaviour of the aerogenerators used in this installation. Additionally, the mechanical and electrical parts are represented with a 2nd order state model, assuming that the created magnetic field has a sine form. This model only allows the use of the torque or the rotor speed as input.

In Table 2, EMF is the electromagnetic field, $\mathrm{R}_{\mathrm{s}}$ is stator resistance and $\mathrm{L}_{\mathrm{d}} \& \mathrm{~L}_{\mathrm{q}}$ are the $\mathrm{d}$ - and $\mathrm{q}$ - axis synchronous inductances.

To validate this model, a load that consumes $4 \mathrm{~kW}$ is connected, considering a wind speed of $8 \mathrm{~m} / \mathrm{s}$; the rotor speed is $83 \mathrm{rpm}$, and the generated root mean square voltage is $373 \mathrm{Vrms}$. At instant $\mathrm{t}=5 \mathrm{~s}$, a step in the wind speed from 8 to $12 \mathrm{~m} / \mathrm{s}$ is performed, and the connected load begins to consume $16 \mathrm{~kW}$. As displayed in Figure 9, when the wind speed step occurs, the generator voltage increases from 373 Vrms to 560 Vrms, and the rotor speed increases from 83 rpm to $125 \mathrm{rpm}$ (i.e., its nominal values). 
Table 2. Parameters of the permanent magnet synchronous machine

\begin{tabular}{lcccccc}
\hline $\begin{array}{l}\text { Back EMF } \\
\text { waveform }\end{array}$ & Rs & Ld \& Lq & $\begin{array}{c}\text { Voltage } \\
\text { constant }\end{array}$ & Inertia & $\begin{array}{c}\text { Friction } \\
\text { factor }\end{array}$ & $\begin{array}{c}\text { Pole } \\
\text { pairs }\end{array}$ \\
\hline Sinusoidal & $0.0485 \Omega$ & $0.000395 \mathrm{H}$ & 6335 Vpeak/krpm & $145.9 \mathrm{~kg} \cdot \mathrm{m}^{2}$ & $0.0004924 \mathrm{~N} \cdot \mathrm{m} \cdot \mathrm{s}$ & 8 \\
\hline
\end{tabular}

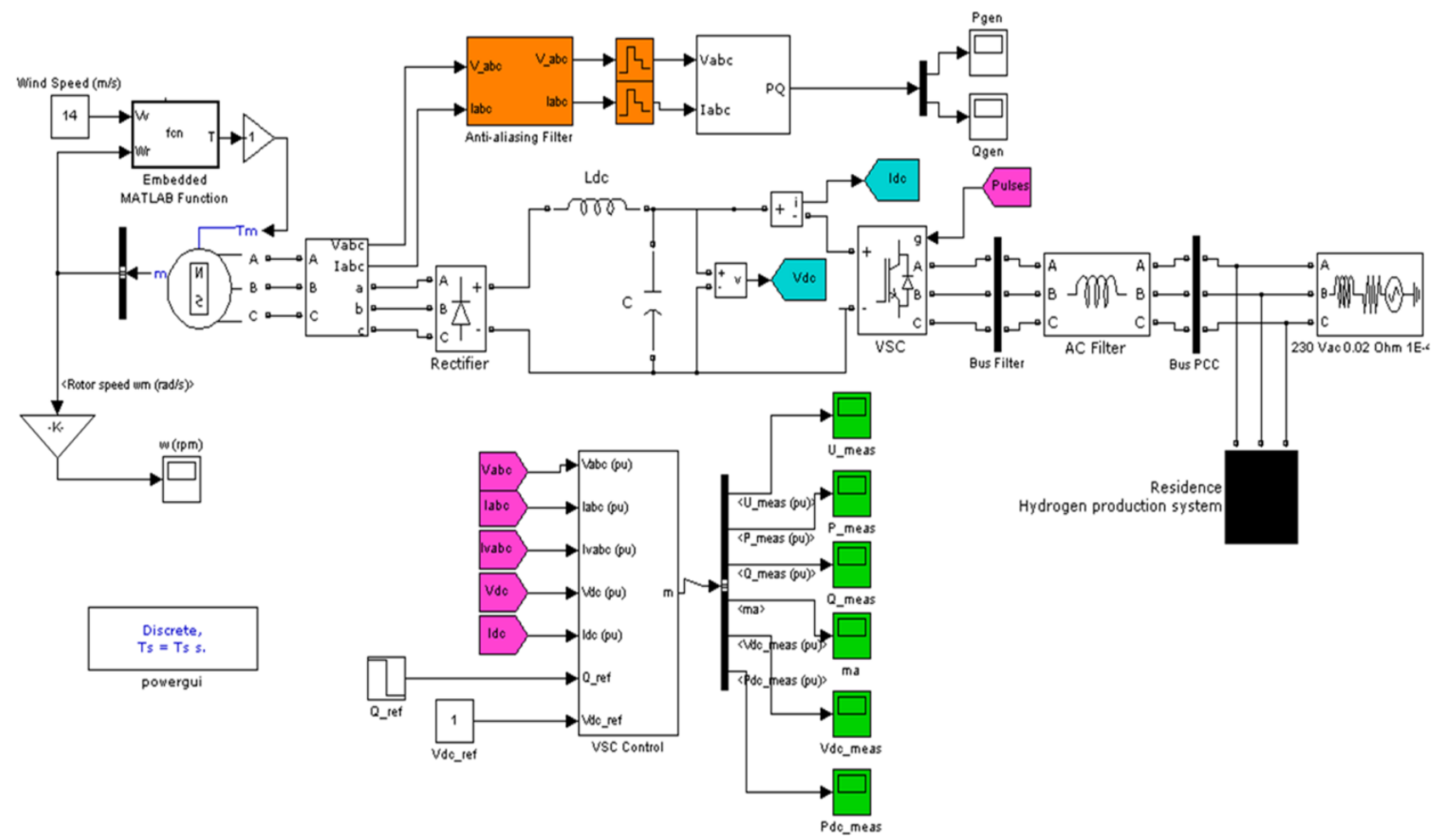

Figure 8. Complete model of the electrical system

Table 3. Parameters of the diode bridge rectifier

\begin{tabular}{cccc}
\hline Snubber ressistance (Rs) & Snubber capacitance (Cs) & $R_{\text {ọn }}$ & Forward voltage (Vf) \\
\hline $100 \Omega$ & $100 \mathrm{nF}$ & $1 \mathrm{~m} \Omega$ & $0 \mathrm{~V}$ \\
\hline
\end{tabular}




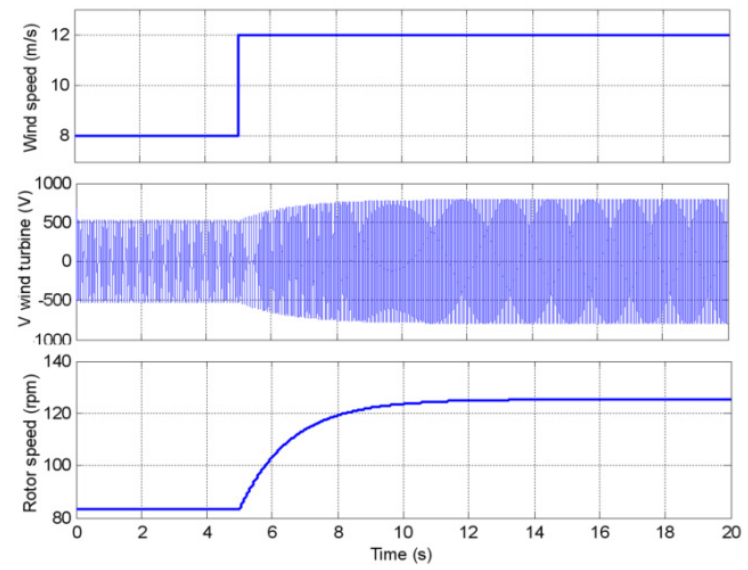

Figure 9. Response of the wind turbine at a wind speed step

\subsubsection{Diode bridge rectifier}

The rectifier consists of 6 diodes in a 3-arm bridge configuration. The block included in the model is taken from the Matlab/Simulink/SimPowerSystems library, and the internal values of the parameters are presented in Table 3.

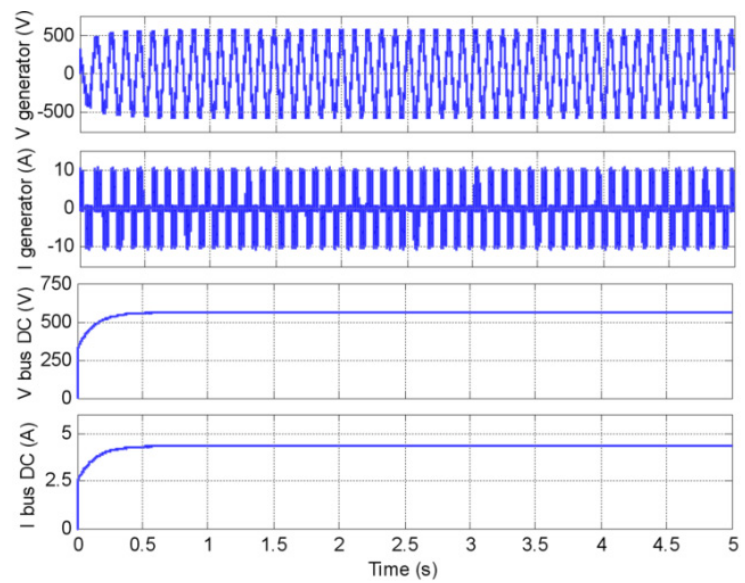

Figure 10. Diode bridge rectifier, input and output voltage and currents, with $\mathrm{L}$ and $\mathrm{C}$

The generator simulated in the previous section is connected to the rectifier input, and the load is connected at the output to check the proper operation. $R_{\text {on }}$ is the conduction resistance. To simplify the model, the forward voltage of diodes (Vf) has been considered null. First, the ripple voltage is $14 \%$, and the ripple current is $16 \%$. To reduce this ripple on the direct current (DC) bus voltage, a 1 $\mathrm{mF}$ capacitor $(\mathrm{C})$ and a $1 \mathrm{mH}$ smoothing inductance (L) are introduced. Figure 10 displays the results of installing these two components in the DC bus. The voltage and current ripple have decreased to $0.35 \%$ and $0.23 \%$, respectively, and the current through the generator has increased its peak value while maintaining its rms value, due to the continuous loading and unloading of the DC bus capacitor.

\subsubsection{Three-phase IGBT inverter}

The role of this inverter is to fit the rectifier output signal so that the generation system can be connected to the grid. The implemented control structure allows the DC bus voltage and the reactive power to be controlled. To make possible a decoupled control of both variables, an abc-dq0 transformation is performed. Once the current and voltage magnitudes are in d-q axes, the 6 IGBT control signals are obtained through two Proportional Integrative control loops (PI) connected in series. Table 4 displays the parameters of the IGBTs used in the inverter.

In this inverter, both the DC bus voltage and the amount of reactive power, to absorb or inject into the network, can be controlled. To validate the performance of this inverter, a voltage control is developed initially, and a reactive control is developed later. Figure 11 illustrates the response to a reference change in the DC bus. Initially, the DC bus is fixed at $380 \mathrm{~V}$, and at instant $\mathrm{t}=10 \mathrm{~s}$, a new reference of $420 \mathrm{~V}$ is assigned. After $3 \mathrm{~s}$, the system reaches the new reference voltage without disturbing the network or affecting the reactive power control, which is still at 0 VAr. An initial peak in reactive power can be observed due to the starting of the generator.

Table 4. Controlled three-phase inverter parameters

\begin{tabular}{lcccccc}
\hline $\begin{array}{l}\text { Snubber } \\
\text { resistance (Rs) }\end{array}$ & $\begin{array}{c}\text { Snubber } \\
\text { capacitance (Cs) }\end{array}$ & $\mathrm{R}_{\text {on }}$ & $\begin{array}{c}\text { Forward voltage } \\
\text { IGBT (Vf) }\end{array}$ & $\begin{array}{c}\text { Fall time } \\
\text { IGBT (Tf) }\end{array}$ & $\begin{array}{c}\text { Tail } \\
\text { time (Tt) }\end{array}$ & $\begin{array}{c}\text { Forward voltaje } \\
\text { diode (Vfd) }\end{array}$ \\
\hline $5 \mathrm{k} \Omega$ & $1 \mu \mathrm{F}$ & $1 \mathrm{~m} \Omega$ & $0 \mathrm{~V}$ & $1 \mu \mathrm{s}$ & $2 \mu \mathrm{s}$ & $0 \mathrm{~V}$ \\
\hline
\end{tabular}



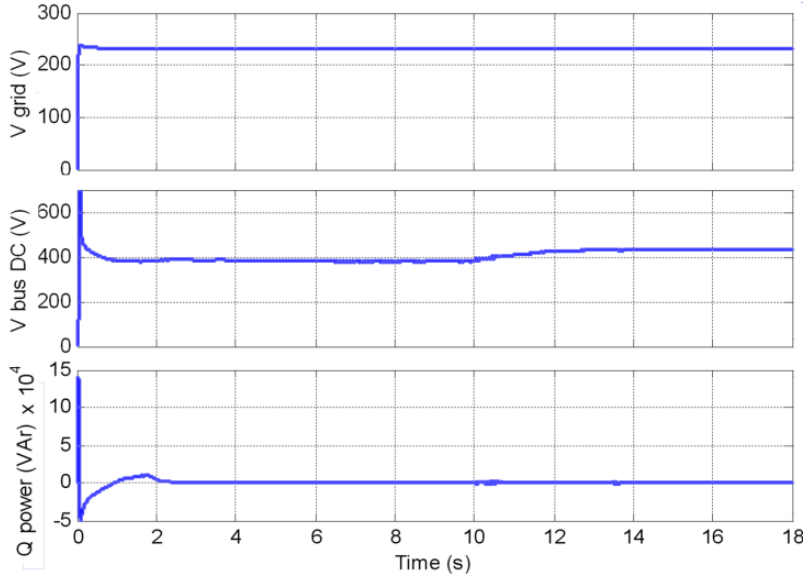

Figure 11. DC bus voltage set-point step response
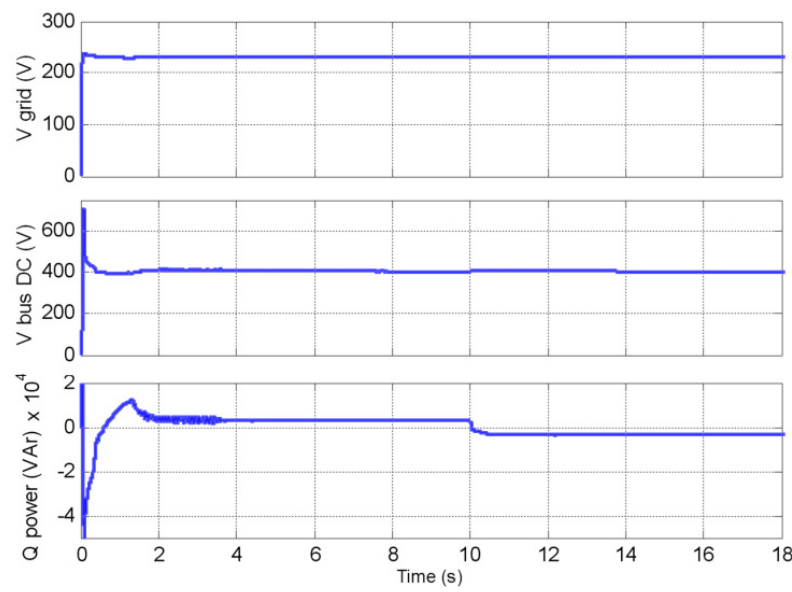

Figure 12. Reactive power set-point step response

Figure 12 displays the response to a change of reactive power reference. Initially, 3,200 VAr is being consumed, and at instant $\mathrm{t}=10 \mathrm{~s}$, a new reference of 3,200 VAr is assigned, but now the reactive power is fed into the grid instead of being consumed; the fit of the control within the new reference can be observed in milliseconds.

\subsubsection{Electrolyzer and compressor system}

This set has been modelled using a gain that is the value of the "electrolyser-compressor" efficiency. For a given input power $\left(\mathrm{P}_{\text {in }}\right)$, there is an output power $\left(\mathrm{P}_{\text {out }}\right)$, as described in equation (10).

$$
P_{\text {out }}=\eta_{\text {electrolyzer }} \cdot \eta_{\text {compressor }} \cdot P_{\text {in }}
$$

The electrolyser efficiency has been obtained using equation (3). Taking into account that the compressor requires $3.1 \mathrm{kWh}$ to compress $1 \mathrm{~kg}$ of hydrogen (from 0.1 $\mathrm{MPa}$ to $35 \mathrm{MPa}$ ), and knowing that $1 \mathrm{~kg}$ of hydrogen is equivalent to $33.33 \mathrm{kWh}$, the efficiency value of the compressor can be determined using equation (11).

$$
\eta_{\text {compressor }}=\frac{33.33 \mathrm{kWh}}{(33.33+3.1) \mathrm{kWh}} \cdot 100=91.49 \%
$$

The output power determined from equation (10) is converted into hydrogen flow generated by the electrolyser, in standard litres per minute (slpm), as presented in equation (12).

$$
P_{\text {out }}(\mathrm{kW}) \cdot \frac{1 \mathrm{~kg} / \mathrm{h}}{33 \mathrm{~kW}} \cdot \frac{1 \mathrm{~h}}{60 \mathrm{~min}} \cdot \frac{11 \cdot 12 \mathrm{~m}^{3}}{1 \mathrm{~kg}} \cdot \frac{1,000 \mathrm{l}}{1 \mathrm{~m}^{3}}=\text { Flow }(\mathrm{slpm})
$$

The production of hydrogen is occurring at a rate of 0.53 $\mathrm{Nm}^{3} / \mathrm{h}$. Thus, taking into account the consumption of 6.7 $\mathrm{kWh} / \mathrm{Nm}^{3}$, the electrical power required for a nominal production of hydrogen is $3.55 \mathrm{~kW}$. Knowing this power value and the nominal voltage of the electrolyser $(230 \mathrm{~V}$, single-phase), the equivalent resistance for the model of the electrolyser-compressor can be obtained as indicated in equation (13).

$$
R=\frac{V_{\text {electrolyser }}{ }^{2}}{P}=\frac{230^{2}}{3,551}=14.89 \Omega
$$

Figure 13 illustrates the hydrogen production when the electrolyser is connected to the nominal voltage of the network. The rms current consumption is $15.44 \mathrm{~A}$, and the hydrogen flow is 9.4 slpm.

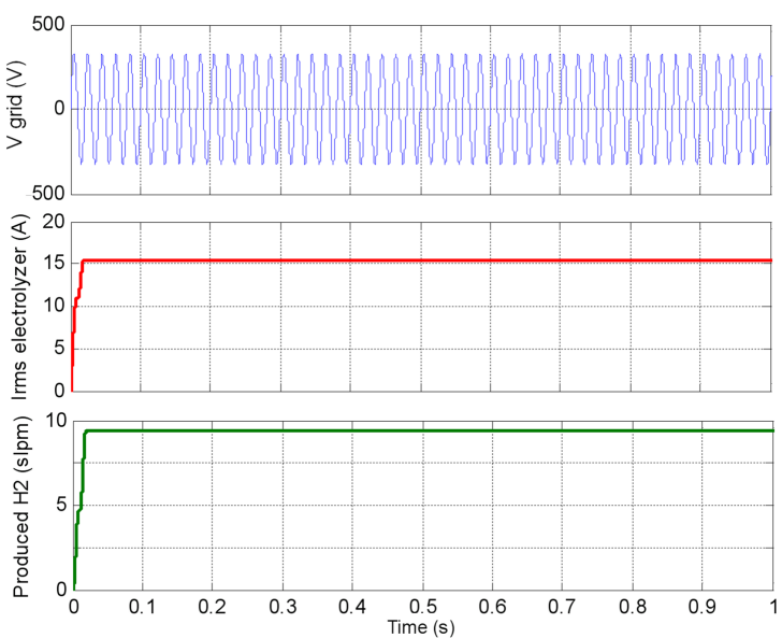

Figure 13. Electrolyzer production at nominal voltage

\subsubsection{Hydrogen tanks (storage and vehicle tanks)}

The hydrogen tanks have been modelled using the ideal gas equation. The tank storage pressure is a function of the hydrogen evacuation into the vehicle tank and the contribution of the electrolyser to the storage tank system, whose dynamics are governed by equations presented [30].

To simplify the model of these tanks, the auxiliary power for the pumps, valves and fans have been ignored (the accuracy of this model is not as important as the other models of the system, as its power consumption is negligible). In addition, the dynamic of compression has not been taken into account. The hydrogen tank inlet and outlet are connected to the electrolyser and the vehicle, respectively, to control the hydrogen flow, as displayed in Figure 14. 


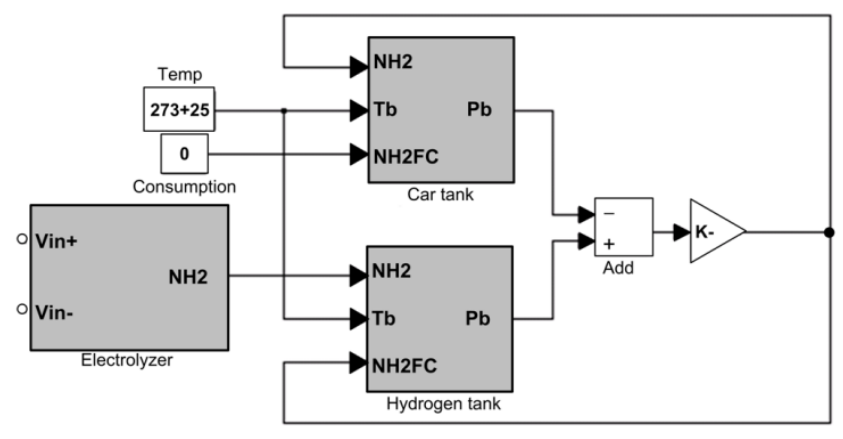

Figure 14. Hydrogen storage tank and car tank connection

When the vehicle tank is being recharged, the hydrogen storage tank receives a reference of consumption, decreasing the initial pressure of the tank. However, when the vehicle is not being recharged and the hydrogen flow that comes from the electrolyser is positive, the pressure of the storage tank increases.

This pressure value is also used to send a stop command to the electrolyser in case of overpressure in the hydrogen tank ( $>45 \mathrm{MPa}$ ), attempting to simulate a security action in the system to prevent potential risks from overpressure. Figure 15 illustrates the evolution of the pressure in the storage tank when the electrolyser supplies the rated hydrogen flow for an operating temperature of $25^{\circ} \mathrm{C}$.

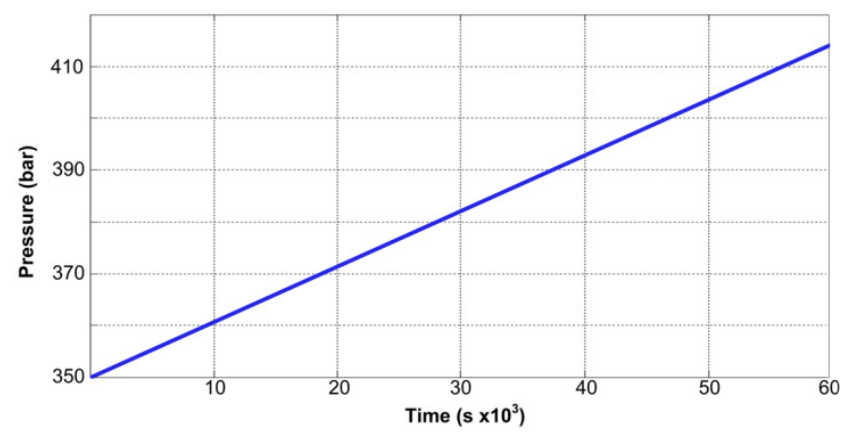

Figure 15. Pressure evolution in the storage tank during the loading of 0.8 $\mathrm{kg}$ of hydrogen

It is assumed that the storage tank is charged with an initial pressure of $35 \mathrm{MPa}$. Once the storage tank is charged at 42 MPa with the amount of hydrogen required for the vehicle, the dispenser is plugged into the vehicle, and the pressure of both storage tanks will equalise after several minutes.

\subsection{Simulation Results}

Once the different models have been developed and validated, several simulations are analysed to verify that the performance of the designed installation is appropriate for the correct operation of the system. Thus, different cases are presented in this subsection. First, a simulation of the system during normal operation has been considered to verify that the installation's performance is stable and operates within the appropriate voltage, current and frequency ranges. An analysis of reactive power injection has been made to understand the system's ability to contribute to the ancillary services. For example, it is interesting to inject reactive power at peak hours to raise the voltage at the connection point, whereas in off-peak hours, it is interesting to absorb reactive power to counteract the capacitive effect of the transmission lines. The simulation of a rapid variation in wind speed is imperative for verifying that the control system responds correctly and the installation's performance is stable. Finally, the power factor correction avoids penalties under contract with the supplier.

\subsubsection{Normal operation}

To simulate the system in normal operation, a wind speed of $10.5 \mathrm{~m} / \mathrm{s}$ has been selected. At this wind speed, each aerogenerator produces $2.5 \mathrm{~kW}$ of power; thus, the four aerogenerators produce $10 \mathrm{~kW}$. In this scenario, a load of 500 $\mathrm{W}$ is connected in the house while the electrolyser is operating at nominal power $(3.55 \mathrm{~kW})$. The active power that can be delivered to the grid is $6 \mathrm{~kW}$, as displayed in Figure 16 ; the set point of the reactive power is set to 0 . Figure 17 indicates that the control of the system correctly responds to this set point.

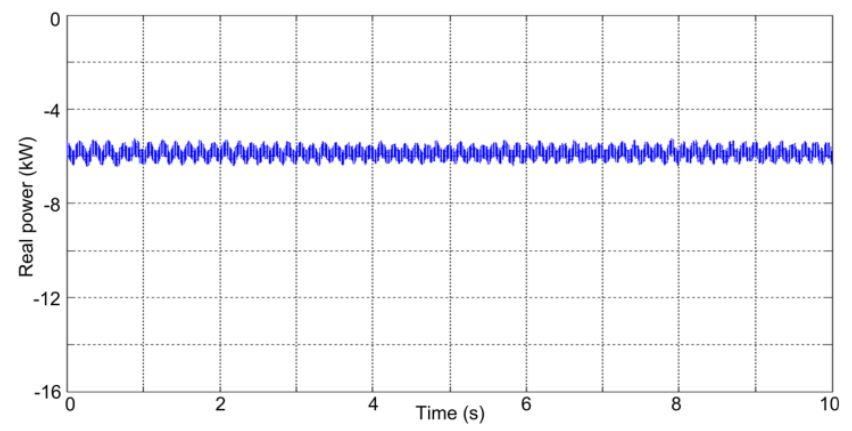

Figure 16. Active power delivered to grid

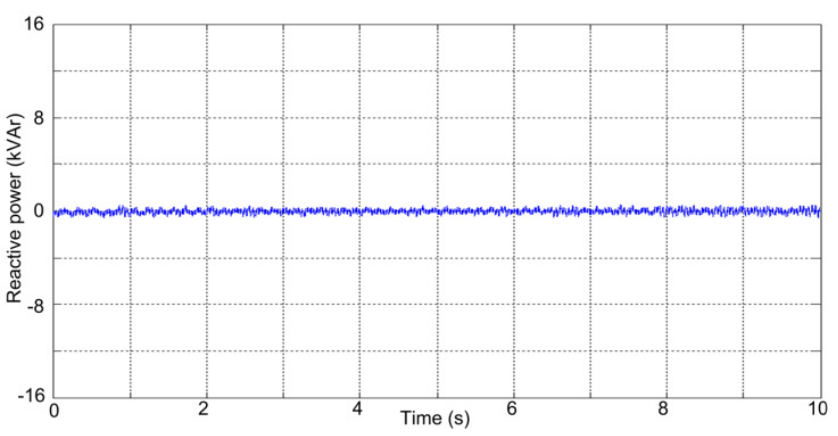

Figure 17. Reactive power delivered to grid

Additionally, Figure 18 illustrates how the DC bus voltage holds in its nominal value due to the inverter control. It delivers the power generated from the aerogenerators to the grid, thereby controlling the DC bus voltage. The maximum ripple of the DC bus voltage is $2 \mathrm{~V}$, and the rotor speed is held in $106 \mathrm{rpm}$, as displayed in Figure 19.

These load conditions are used in the next simulations to compare the behaviour of the system under different conditions. 


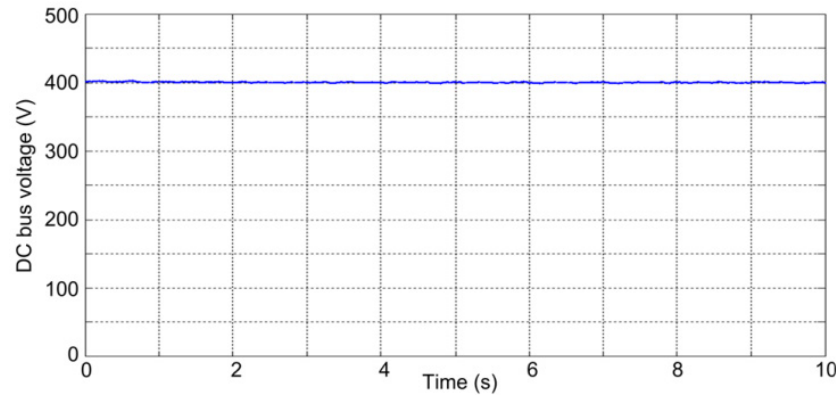

Figure 18. DC bus voltage

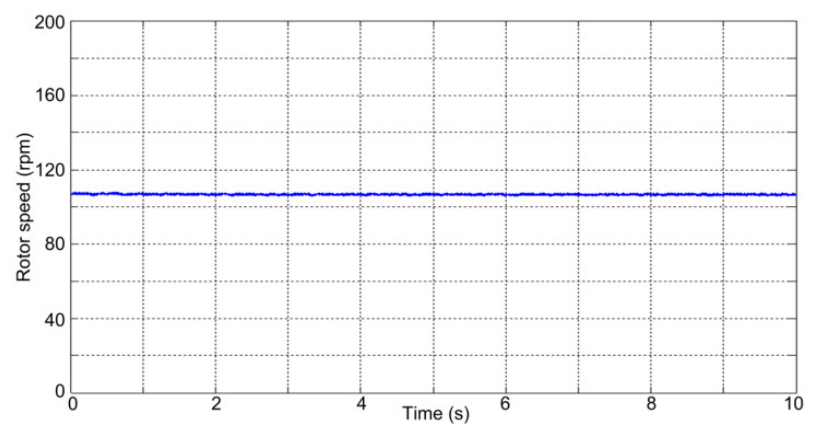

Figure 19. Rotor speed (rpm)

\subsubsection{Reactive Power Injection Response}

Figure 20 illustrates the response of the grid voltage when the set point of reactive power is fixed to $-16,000 \mathrm{VAr}$. The negative sign indicates that the reactive power is being injected into the grid. This injection begins at instant $\mathrm{t}=2 \mathrm{~s}$. As can be observed, the reactive power does not reach the reference because of the converter limitation. The converter is also injecting active power (as priority control), and the only way to maintain that active power is to decrease the reactive power, in this case to $-6,000 \mathrm{VAr}$. A 6,000 $\mathrm{VAr}$ reactive power injection to the grid causes a $0.5 \mathrm{~V}$ increase in the grid voltage, as illustrated in Figure 20. This voltage increase depends on the short-circuit power of the grid at the interconnection point; in this case, the short-circuit grid power is $1.6 \mathrm{MVA}$.

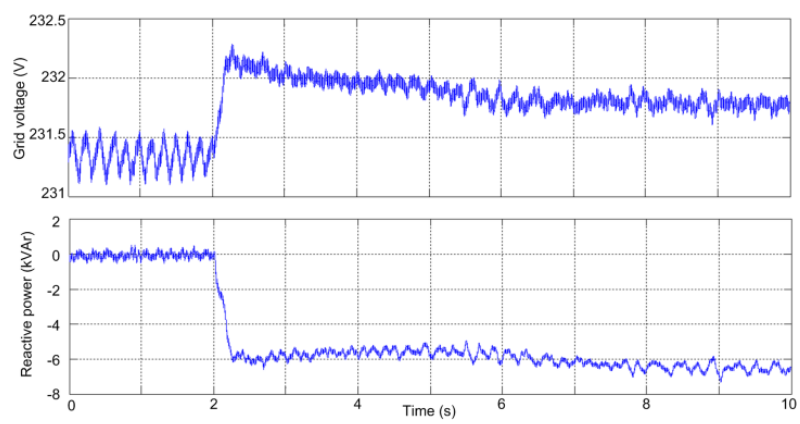

Figure 20. Response to reactive injection, at instant $2 \mathrm{~s}$

\subsubsection{Wind speed variation response}

To check the system performance under wind changes, a wind step of $10.5 \mathrm{~m} / \mathrm{s}$ to $8 \mathrm{~m} / \mathrm{s}$ at instant $\mathrm{t}=2 \mathrm{~s}$ has been analysed. The load conditions of both the electrolyser and the house are the same as those presented in 3.2.1 (i.e., the total load consumes $4.05 \mathrm{~kW}$ ). The power generated by the four wind turbines at $10.5 \mathrm{~m} / \mathrm{s}$ is $10 \mathrm{~kW}$. As displayed in Figure 21 , when the wind speed is reduced, the wind turbine set is almost able to supply the needs of the house consumption and the hydrogen production system, so the system does not deliver energy to the grid. The DC bus voltage decreases when the wind decrease occurs, but the control system works by drawing less current from the DC bus in order to restore the voltage to its nominal value. The rotor speed drop is insignificant because the resistive load on the generator is the same before and after the step.

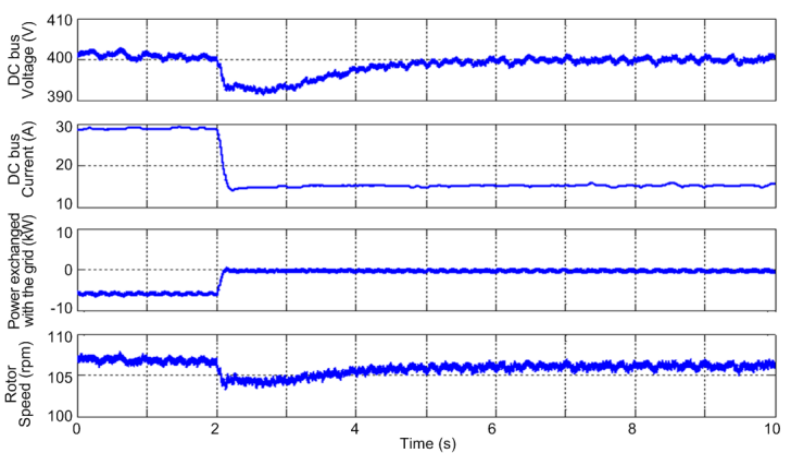

Figure 21. Wind speed variation from $10.5 \mathrm{~m} / \mathrm{s}$ to $8 \mathrm{~m} / \mathrm{s}$

\subsubsection{Power Factor Correction}

Some loads that are connected in a house contribute to the deterioration of the power factor, making it inductive. The same effect can be conferred by the compressor and the chiller. Typically, electrical companies penalise this inductive power factor with a financial penalty to encourage customers to achieve a unity power factor.

Figure 22 illustrates a situation where the system is producing hydrogen with a power factor of 0.8 inductive seen by the network; all the power generated is active, and the reactive power is zero. At instant $\mathrm{t}=2 \mathrm{~s}$, reactive power is injected to correct the power factor. The power factor observed by the network is unitary after the injection of this reactive power.
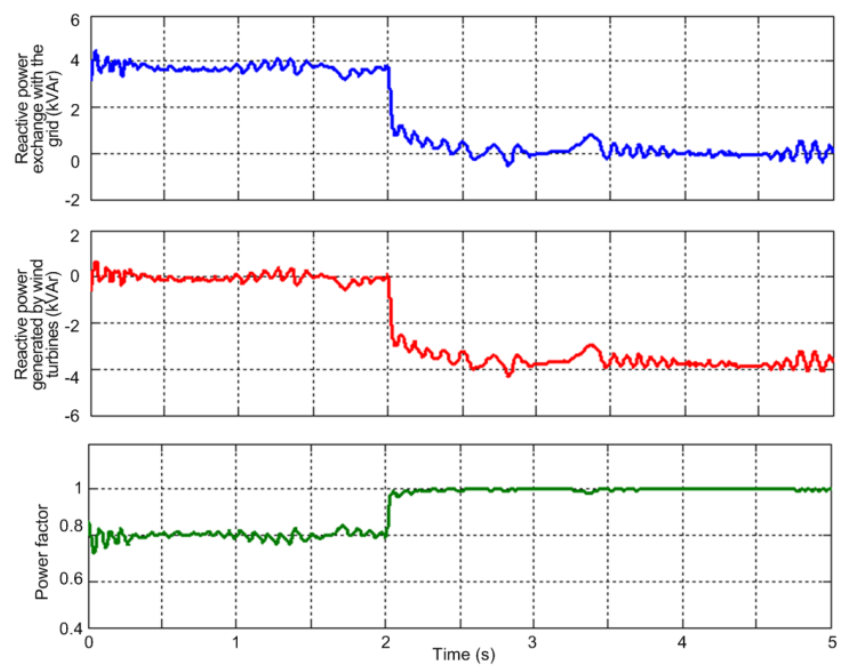

Figure 22. Reactive power generated and absorbed from the grid and power factor 
Table 5. Description of investment costs

\begin{tabular}{|c|c|c|c|c|}
\hline ITEM & PRODUCT DESCRIPTION & QUANTITY & $\begin{array}{l}\text { COST PER } \\
\text { UNIT(€/u) }\end{array}$ & $\cos T(\epsilon)$ \\
\hline WATER TANK & NORWESCO WATER $80 \mathrm{G}$. TANK & 1 & 230 & 230 \\
\hline DEIONIZER & OTG2-SDIL & 1 & 480 & 480 \\
\hline ELECTROLYZER & PEM HOGEN S20 & 1 & 11,100 & 11,100 \\
\hline WIND TURBINE & GENX-UGE-4KW & 4 & 8,075 & 32,300 \\
\hline TOWER & $18 \mathrm{ft}$ X-UGE-4K-T550 & 4 & 1,600 & 6,400 \\
\hline \multirow{2}{*}{$\begin{array}{l}\text { PO WIND } \\
\text { INTERFACE BOX } \\
\text { PO GRID-TIE } \\
\text { INVERTER }\end{array}$} & PVI-7200 & 4 & 1,525 & 6,100 \\
\hline & PVI-4200 & 4 & 2,800 & 11,200 \\
\hline INSTALLATION & & 4 & 400 & 1,600 \\
\hline $\begin{array}{l}\text { SUBTOTAL WIND } \\
\text { TURBINE SYSTEM }\end{array}$ & & & & 57,600 \\
\hline COMPRESSOR & HYDRO-PAC C06-03-140/300LX & 1 & 8,500 & 8,500 \\
\hline CHILLER & & 1 & 2,000 & 2,000 \\
\hline STORAGE TANK & W076 HYDROGEN DYNECELL & 1 & 4,800 & 4,800 \\
\hline DISPENSER & & 1 & 1,000 & 1,000 \\
\hline SAFETY EQUIPMENT & & 1 & 1,200 & 1,200 \\
\hline \multicolumn{4}{|l|}{ SUBTOTAL } & $86,910 €$ \\
\hline \multicolumn{4}{|c|}{ STATE AID TO RENEWABLE ENERGY INVESTMENTS } & $27,000 €$ \\
\hline \multicolumn{4}{|c|}{ TOTAL INVESTMENT COSTS } & $59,910 €$ \\
\hline
\end{tabular}

\section{Economical Analysis}

Finally, an economical estimation of the installation, considering not only costs but also possible revenues, has been conducted.

First, costs associated with the initial investment capital are included. The obtained capital cost of the installation is $86,910 €$, as presented in Table 5; however, government aid must also be considered. The aid is available to help consumers purchase small wind systems for homes, farms, etc. In Spain, this aid is $2.5 € / \mathrm{W}$ for the first $3 \mathrm{~kW}$ and 1.5 $€ / \mathrm{W}$ for additional $\mathrm{kW}$ up to a maximum of $100 \mathrm{~kW}$ of total power, and limited to $100,000 €$ [31]. In the design presented in this paper, this aid is estimated as:

$(3 \mathrm{~kW} \cdot 2,500 € / \mathrm{kW})+(13 \mathrm{~kW} \cdot 1,500 € / \mathrm{kW})=27,000 €$

Taking this option into account, new figures are obtained, bringing the total capital cost of the system to $59,910 €$. Within this amount, the cost of wind turbine system accounts for $66.2 \%$, the electrolyser for $12.7 \%$ and the compressor for $9.7 \%$.

The expected lifetime of the designed system is approximately 20 years. To make the system operational during that period of time, a number of costs (expenses) have been taken into account related to the maintenance of the facility (labour costs and maintenance of the equipment), as detailed in Table 6 .
Table 6. Expenses per year

\begin{tabular}{lc}
\hline \multicolumn{1}{c}{ DESCRIPTION } & COST PER YEAR \\
\hline LABOR MAINTENANCE & $1,500 €$ \\
EQUIPMENT MAINTENANCE & $500 €$ \\
\hline TOTAL EXPENSES & $2,000 €$ \\
\hline
\end{tabular}

Finally, as sources of revenue, the following have been considered: the fuel of the vehicle, electricity saved in the house, the sale of surplus power to the grid and the cost for avoided $\mathrm{CO}_{2}$ emissions. All of these aspects are presented in Table 7.

Table 7. Revenues per year

\begin{tabular}{lc}
\hline \multicolumn{1}{c}{ DESCRIPTION } & REVENUES PER YEAR \\
\hline DISPENSING HYDROGEN (FUEL ECONOMY) & $2,111 €$ \\
ELECTRICITY CONSUMPTION SAVINGS IN THE HOUSE & $682 €$ \\
SALE OF SURPLUS ELECTRICITY TO THE GRID & $266 €$ \\
COST OF AVOIDED CARBON DIOXIDE & $70 €$ \\
\hline TOTAL REVENUES & $3,129 €$ \\
\hline
\end{tabular}

- Fuel economy. This aspect has been analysed based on the avoided cost of oil consumption per vehicle, covering $20,550 \mathrm{~km} /$ year, considering an average consumption of 7.5 
$1 / 100 \mathrm{~km} \mathrm{[32]} \mathrm{and} \mathrm{a} \mathrm{fuel} \mathrm{price} \mathrm{of} 1.37 € / 1$ [33].

$20,550 \mathrm{~km} /$ year $\cdot 7.5$ liter $/ 100 \mathrm{~km} \cdot 1.37 € /$ liter $=2,111$ $€ /$ year

- Electricity consumption savings at home. These savings have been considered based on the avoided cost of consumption of $4,794 \mathrm{kWh} /$ year of electricity, considering the cost of that electricity at approximately $0.1423 € / \mathrm{kWh}$ [34].

\section{$4,794 \mathrm{kWh} /$ year $\cdot 0.1423 € / \mathrm{kWh}=682 € /$ year}

- Sale of surplus electricity. The income from the sale of $3,374.7 \mathrm{kWh} /$ year of electricity to the grid has been calculated using the regulated tariff, which provides a payment of $0.079084 €$ per $\mathrm{kWh}$ sold, for the special regime installations (group b.2.1) under law in Spain [35].

$3,374.7 \mathrm{kWh} /$ year $\cdot 0.079084 € / \mathrm{kWh}=266 € /$ year

- Cost of avoided carbon dioxide emissions. First, the amount of $\mathrm{CO}_{2}$ emissions avoided by the $31,021 \mathrm{kWh} /$ year generated by renewable energy should be estimated. According to a report by the Institute for Energy Diversification and Saving of Energy [36], $1 \mathrm{MWh}$ would generate $0.25 \mathrm{tCO}_{2}$. Therefore, the avoided $\mathrm{CO}_{2}$ emissions are as follow:

$31.02 \mathrm{MWh} /$ year $\cdot 0.25 \mathrm{tCO}_{2} / \mathrm{MWh}=7.75 \mathrm{tCO}_{2} /$ year

With regard to the cost of $\mathrm{CO}_{2}$ emission rates, it should be mentioned that estimations of the social cost are highly uncertain. The wide range of estimations is explained mostly by underlying uncertainties in the science of climate change, different choices of the discount rate, different valuations of economic and non-economic impacts and how potential catastrophic impacts are estimated. According to the European bourse for European Unit Allowances and Carbon Credits [37], the current reference price of carbon dioxide emissions is $9 € /$ t. Therefore, the cost of avoided $\mathrm{CO}_{2}$ emissions can be calculated as:

\section{$7.75 \mathrm{tCO}_{2} /$ year $\cdot 9 € / \mathrm{t}=70 € /$ year}

Considering the revenues and expenses listed above, for the first year, a favourable result can be obtained of 3,129 $2,000=1,129 € /$ year. However, the calculations presented have been made based on current prices. Given that the expected life of the installation is approximately 20 years, futures prices should also be considered. However, due to the current variability of prices, the difficulty of predicting them over such a long period is remarkable, and the reliability of the estimations could be questionable.

\section{Conclusions}

This paper has presented the design, analysis and simulations of a residential microgeneration system based on renewable energy, to generate hydrogen to supply a fuel cell vehicle and meet the electricity needs of the residence.

Taking into account the efficiency, cost, safety and reliability characteristics, a solution based on wind energy has been chosen. A system of four vertical axis wind turbines located on towers has been selected, which also incorporates lighting to minimise the visual impact. The energy supplied by these wind turbines is used to supply an electrolyser, ancillary equipment, residence consumption and, if necessary, to inject surplus energy into the grid. To optimise the system operation, the water required for electrolysis is collected from the rain. In critical situations of wind activity, maintenance, lack of rain or other events, the fuelling station can be fed from the power network and the main water supply.

The residential station design comes from meeting the needs of hydrogen generation. The fuel cell vehicle requirements have been fixed at $56.3 \mathrm{~km} /$ day or 20,550 $\mathrm{km} /$ year, $70.8 \mathrm{~km} / \mathrm{kg}$ of hydrogen consumption and a residential consumption of $4,794 \mathrm{kWh}$. The electrolyser, deioniser, water flow, compressor, chiller, storage tank and hydrogen dispensing are sized and chosen based on the needs for hydrogen generation.

The choice of the wind turbines stems from the analysis of the selected area wind characteristics. The four vertical axis turbines chosen provide $31,021 \mathrm{kWh} /$ year, which is enough energy to meet the electrical needs of the residential station and to inject 3,374 kWh/year into the grid.

Three representative wind profiles have been selected with high, standard and low wind production, which allows the analysis of different generation scenarios and the consumption and exchange of energy with the main grid. In this context, the maximum and minimum wind speeds for the different cases are $15 \mathrm{~m} / \mathrm{s}$ and $1 \mathrm{~m} / \mathrm{s}$, respectively. The maximum and minimum power generated in the different scenarios is $16,750 \mathrm{~W}$ and $0 \mathrm{~W}$, respectively.

Simulations have also been performed, both in normal operation as well as in other scenarios, to validate the correct performance of the whole designed system. Finally, an economical analysis has been conducted covering different aspects, such as capital investment, existing subsidies for renewable power generation and revenues. The obtained results indicate that the proposed installation is viable.

\section{Acknowledgements}

The work presented in this chapter has been supported by the Basque Government (Ref. IT532-10) and the University of the Basque Country (UFI 11/28).

\section{REFERENCES}

[1] Acorede M.F., Hizam H., Pouresmaeil E., Distributed Energy Resources and Benefits to the Environment, Renewable and Sustainable Energy Reviews, 2010;14:724-34.

[2] Midilli A., Dincer I., Hydrogen as a renewable and sustainable solution in reducing global fossil fuel consumption, International Journal of Hydrogen Energy, 2008;33:4209-22. 
[3] Veziroglu A., Macario R., Fuel cell vehicles: State of the art with economic and environmental concerns, International Journal of Hydrogen Energy, 2011;36:25-43.

[4] U.S. Department of Energy, Hydrogen, Fuel cells, and Infrastructure Technologies Program Multi-Year Research, Development and Demonstration Plan: Planned Program Activities for 2005-2015, Section 3.4 Fuel Cells, 2007, $<\mathrm{http}$ ://www1.eere.energy.gov/hydrogenandfuelcells/mypp/> [accessed 13.1.12].

[5] U.S. Department of Energy, Fuel Cell School Buses: Report to Congress, 2008,

$<$ http://www.hydrogen.energy.gov/pdfs/epact_743_fuel_cell _school_bus.pdf $>$ [accessed 13.1.12].

[6] Moore R.M., Hauer K.H., Ramaswany S., Cunningham J.M., Energy utilization and efficiency analysis for hydrogen fuel cell vehicles, Journal of Power Sources, 2006;159:1214-30.

[7] Bilgen E., Domestic hydrogen production using renewable energy, Solar Energy, 2004; 77:47-55.

[8] Shiga H., Shinda K., Hagiwara K., Tsutsumi A., Sakurai M., Yoshida K., Bilgen E., Large-scale hydrogen production from biogas, International Journal of Hydrogen Energy, 1998;23:631-40.

[9] Ewan B.C.R., Allen R.W.K., A figure of merit assessment of the routes to hydrogen, International Journal of Hydrogen Energy, 2008;30:809-19.

[10] San Martín J.I., Zamora I., San Martín J.J., Aperribay V., Eguia P., Hybrid fuel cells technologies for electrical microgrids, Electric Power System Research, 2010;80:993-1005

[11] Wind data, $<$ http://www.globalwindmap.com/VisorCENER_EN/mapvie wer.jsf?width $=1293 \&$ height $=801>$ [accessed 10.12.11].

[12] Jensen S.H., Larsen P.H., Mogensen M., Hydrogen and synthetic fuel production from renewable energy sources, International Journal of Hydrogen Energy, 2007;32:3253-7.

[13] Bockris J.O.M., Veziroglu T.N., Estimates of the price of hydrogen as a medium for wind and solar sources, International Journal of Hydrogen Energy, 2007;32:1605-10.

[14] Hydrogen data, <http://www.brunopolletresearch.com/Energ y_Data.pdf $>$ [accessed 13.12.11].

[15] Electrolyzer data, $<$ http://www.protononsite.com/pdf/HOGEN_S.pdf $>$ [accessed 13.12.11].

[16] Deionizer data, <http://www.portablewaterdi.com/deionizers .php $>$ [accessed 13.12.11].

[17] Tank data $<$ http://tanksforless.com/75-Gallon-Norwesco-Vertical-Stora ge-Tank-41863.htm $>$ [accessed 12.1.12].

[18] Compressor data, <http://hasmak.com.tr/hydropac/LX\%20H ydrogen\%20Brochure\%2010_2008.pdf $>$ [accessed 13.12.11].

[19] <http://www.hydrogen.energy.gov/pdfs/9013_energy_requir ements_for_hydrogen_gas_compression.pdf $>$ [accessed 13 . 12.11].

[20] Chiller data,

$<$ http://www.lytron.com/cooling-systems/standard/recirculati
ng-chillers-kodiak.aspx?tab=Specs $>$ [accessed 13.12.11]

[21] Zhang J., Fisher T.S., Ramchandran P.V., Gore J.P., Mudawar I., A review of heat transfer issues in hydrogen storage technologies, Journal of Heat Transfer, 2005;127:1391-9.

[22] David E., An overview of advanced materials for hydrogen storage, Journal of Materials Processing Technology, 2005;162-163:169-77.

[23] Sandi G., Hydrogen storage and its limitation, Electrochemical Society Interface, 2004;13:40-5.

[24] Hydrogen storage tank data, $<$ http://www.dynetek.com/pdf/4 50_Bar_Specifications.pdf $>$ [accessed 12.1.12].

[25] Hydrogen dispenser data, <http://www.weh.com/desktopdef ault.aspx $>$ [accessed 12.1.12].

[26] Ucar A., Balo F., Evaluation of wind energy potential and electricity generation at six locations in Turkey, Applied Energy, 2009;86:1864-72.

[27] Wind turbine data, <http://www.genxfuel.com/resources/Ge nX4kWWindTurbine.pdf $>$ [accessed 5.10.11].

[28] <https://www.iberdrola.es/webibd/corporativa/iberdrola?IDP $\mathrm{AG}=$ ESWEBCLIINSASEINFSUMTAR $>$ [accessed 9.1.12].

[29] <http://www.swagelok.com> [accessed 9.1.12]; $<$ http://www.sigmaaldrich.com $>$ [accessed 9.1.12]; $<$ http://www.bauer-kompressoren.de $>\quad$ [accessed 9.1.12]; $<$ http://www.ushosecorp.com/index.cfm/datakey/3/productI $\mathrm{D} / 1558>$ [accessed 9.1.12].

[30] Abrahams R., DuChamper A., Planz A., Models for molecular prediction for engineers, 1987.

[31] <http://www.eve.es/web/Energias-Renovables/productos/Ay udas-(1)/Detalle-Ayuda.aspx?IdAyuda $=154 \&$ categoria $=$ Tod aslascategorias $>$ [accessed 14.1.12].

[32] Institute for Energy Diversification and Saving (IDAE), <http://www.idae.es/Coches/PDF/GuiaFinalN.pdf $>$ [accessed 14.1.12].

[33] Ministry of Industry, Energy and Tourism of Spain, $<$ http://geoportal.mityc.es/hidrocarburos/eess/\#> [accessed 10.1.12].

[34] Official State Gazette, <http://www.boe.es/boe/dias/2011/09/ 30/pdfs/BOE-A-2011-15362.pdf $>$ [accessed 10.1.12].

[35] Official State Gazette, <http://www.boe.es/boe/dias/2010/12/ 29/pdfs/BOE-A-2010-20002.pdf $>$ [accessed 10.1.12].

[36] Institute for Energy Diversification and Saving(IDAE), <http://www.idae.es/index.php/mod.documen tos $/$ mem.descarga? file $=/$ documentos Factores de Conversi on_Energia_y_CO2_(2010)_931cce-1e.pdf $>$ [accessed 10.1.1 2].

[37] <http://www.sendeco2.com/index-uk.asp $>$ [accessed 18.1.12 ]. 